\title{
Review Article \\ B-Cell Activating Factor as a Cancer Biomarker and Its Implications in Cancer-Related Cachexia
}

\author{
Michal Rihacek, ${ }^{1,2}$ Julie Bienertova-Vasku, ${ }^{2,3}$ Dalibor Valik, ${ }^{2,4}$ Jaroslav Sterba, ${ }^{1,2}$ \\ Katerina Pilatova, ${ }^{2,4}$ and Lenka Zdrazilova-Dubska ${ }^{2,4}$ \\ ${ }^{1}$ Department of Pediatric Oncology, University Hospital and Faculty of Medicine, Masaryk University, Cernopolni 9, \\ 61300 Brno, Czech Republic \\ ${ }^{2}$ Regional Centre for Applied Molecular Oncology, Masaryk Memorial Cancer Institute, Zluty Kopec 7, 65653 Brno, Czech Republic \\ ${ }^{3}$ Department of Pathological Physiology, Faculty of Medicine, Masaryk University, Kamenice 5, 62500 Brno, Czech Republic \\ ${ }^{4}$ Advanced Cell Immunotherapy Unit, Department of Pharmacology, Faculty of Medicine, Masaryk University, Kamenice 5, \\ 62500 Brno, Czech Republic
}

Correspondence should be addressed to Lenka Zdrazilova-Dubska; lzd@mail.muni.cz

Received 22 October 2014; Accepted 28 April 2015

Academic Editor: Olive Joy Wolfe

Copyright (C) 2015 Michal Rihacek et al. This is an open access article distributed under the Creative Commons Attribution License, which permits unrestricted use, distribution, and reproduction in any medium, provided the original work is properly cited.

\begin{abstract}
B-cell activating factor (BAFF) is a cytokine and adipokine of the TNF ligand superfamily. The main biological function of BAFF in maintaining the maturation of B-cells to plasma cells has recently made it a target of the first FDA-approved selective BAFF antibody, belimumab, for the therapy of systemic lupus erythematosus. Concomitantly, the role of BAFF in cancer has been a subject of research since its discovery. Here we review BAFF as a biomarker of malignant disease activity and prognostic factor in B-cell derived malignancies such as multiple myeloma. Moreover, anti-BAFF therapy seems to be a promising approach in treatment of B-cell derived leukemias/lymphomas. In nonhematologic solid tumors, BAFF may contribute to cancer progression by mechanisms both dependent on and independent of BAFF's proinflammatory role. We also describe ongoing research into the pathophysiological link between BAFF and cancer-related cachexia. BAFF has been shown to contribute to inflammation and insulin resistance which are known to worsen cancer cachexia syndrome. Taking all the above together, BAFF is emerging as a biomarker of several malignancies and a possible hallmark of cancer cachexia.
\end{abstract}

\section{The BAFF/BAFF-Receptor System Is Essential for B-Cell and Plasma Cell Development and Function}

B-cell activating factor (BAFF, BLyS, TNFSF13B, TALL-1, and CD257) is a 285-amino-acid type II transmembrane protein that belongs to the superfamily of 19 known TNF ligands $[1,2]$. Since its discovery, BAFF has been confirmed as a necessary element in B-cell proliferation and as a specific immunity response enhancer [3]. BAFF deficiency leads to almost complete loss of follicular and marginal zone B-cell production in murine secondary lymphoid organs [4]. BAFF neutralization by soluble receptor decoys blocks the Th1 to Th2 transition, thereby leading to inhibition of antigenspecific antibody production $[4,5]$. BAFF also mediates immunoglobulin isotype switching in B-cells [6]. BAFF signaling is potentiated by BCR ligation [7] and enhances survival in B-cells via activation of NF- $\kappa$ B pathway.

Three receptors from the 29-member TNF receptor superfamily are now confirmed to interact with BAFF: BAFF$\mathrm{R}$, TACI, and BCMA [8] (Table 1). BAFF-R seems to be the most important receptor for BAFF, with a critical role in regulating $B$-cell survival [9]. Mice with a naturally occurring mutation in the BAFF-R locus (A/WySnJ mice) have a qualitatively similar phenotype to mice with BAFF deficiency, suggesting a unique role of BAFF-R in B-cell development that cannot be compensated by the two other BAFF receptors, TACI and BCMA $[9,10]$.

Unlike BAFF-R, TACI binds two ligands from the TNF superfamily: BAFF and APRIL [11]. The role of TACI in BAFF signaling is complex, as it induces both activation and inhibition of the NF- $\kappa$ B pathway. When ligated by TACI, 
TABLE 1: Overview of BAFF receptors.

\begin{tabular}{|c|c|c|c|c|c|c|c|}
\hline & Gene & Forms & Ligands & $\begin{array}{l}\text { Affinity to BAFF } \\
\left(K_{D}\right)\end{array}$ & $\begin{array}{c}\text { Tissue } \\
\text { expression }\end{array}$ & Function & Clinical relevance \\
\hline $\begin{array}{l}\text { BAFF-R } \\
\text { (BAFF-receptor, } \\
\text { TNFRSF13C, BLyS, } \\
\text { BR3, CD268) [13] }\end{array}$ & $\begin{array}{c}\text { 22q13.2 } \\
3 \text { exons }[13]\end{array}$ & $\begin{array}{l}\text { Membrane } \\
\text { bound, } \\
\text { soluble } \\
\text { (produced by } \\
\text { decidual } \\
\text { cells) }[8,14]\end{array}$ & $\begin{array}{l}\text { BAFF } \\
{[8]}\end{array}$ & $16 \mathrm{nmol} \cdot 1^{-1}[8]$ & $\begin{array}{c}\text { B-, T-cells } \\
{[15,16]} \\
\text { mature and } \\
\text { immature } \\
\text { adipose tissue } \\
{[17]}\end{array}$ & $\begin{array}{c}\text { B-cell } \\
\text { proliferation } \\
\text { [18], } \\
\text { T-cell } \\
\text { proliferation } \\
{[16]}\end{array}$ & $\begin{array}{c}\text { BAFF-R is } \\
\text { constitutively } \\
\text { saturated in } \\
\text { autoimmune and } \\
\text { lymphoproliferative } \\
\text { diseases }[15,19,20]\end{array}$ \\
\hline $\begin{array}{l}\text { TACI } \\
\text { (transmembrane } \\
\text { activator and } \\
\text { calcium } \\
\text { signal-modulating } \\
\text { cyclophilin ligand, } \\
\text { TNFRSF13B, } \\
\text { CD267) [21] }\end{array}$ & $\begin{array}{c}17 p 11.2 \\
5 \text { exons }[21]\end{array}$ & $\begin{array}{l}\text { Membrane } \\
\text { bound [8] }\end{array}$ & $\begin{array}{l}\text { BAFF, } \\
\text { APRIL } \\
{[8]}\end{array}$ & $146 \mathrm{nmol} \cdot \mathrm{l}^{-1}[22]$ & $\begin{array}{c}\text { B-, T-cells } \\
\text { immature } \\
\text { adipose tissue } \\
{[17]}\end{array}$ & $\begin{array}{c}\text { T-cell activation } \\
{[23] \text { and }} \\
\text { humoral } \\
\text { immunity } \\
\text { response } \\
\text { modulation } \\
{[24,25]}\end{array}$ & $\begin{array}{c}\text { Mutations may result } \\
\text { in common variable } \\
\text { immunodeficiency } \\
{[26,27]}\end{array}$ \\
\hline $\begin{array}{l}\text { BCMA } \\
\text { (B-cell maturation } \\
\text { antigen, } \\
\text { TNFRSF17) [28] }\end{array}$ & $\begin{array}{c}\text { 16p13.1 } \\
3 \text { exons }[28]\end{array}$ & $\begin{array}{l}\text { Membrane } \\
\text { bound [8] }\end{array}$ & $\begin{array}{c}\text { APRIL } \\
\text { (BAFF) } \\
{[8]}\end{array}$ & $1600 \mathrm{nmol} \cdot \mathrm{l}^{-1}[8]$ & $\begin{array}{c}\text { B-cells } \\
\text { immature } \\
{[17]}\end{array}$ & $\begin{array}{c}\text { Long-term } \\
\text { plasma cell } \\
\text { survival, B-cell } \\
\text { antigen } \\
\text { presentation } \\
\text { [29] }\end{array}$ & $\begin{array}{l}\text { Protection of multiple } \\
\text { myeloma cells from } \\
\text { apoptosis }[30,31]\end{array}$ \\
\hline
\end{tabular}

$\mathrm{BAFF}$ has been shown to be a negative regulator of $\mathrm{B}$ cell expansion. $\mathrm{TACI}^{-/-}$mice show B-cell hyperplasia and elevated levels of circulating antibodies, resulting in fatal autoimmune glomerulonephritis and splenomegaly [11, 12].

The primary ligand of BCMA is APRIL, although BAFF also binds to this receptor, albeit with low affinity [8]. A significant role for BCMA was determined in multiple myeloma. BCMA ligation provides survival signals for abnormal plasma cells to evade apoptosis $[30,32]$. Notably, all three $B A F F$ receptors activate NF- $\kappa$ B pathways via TRAF signaling molecules $[8,33,34]$.

\section{Cytokine and Adipokine BAFF Is Expressed Ubiquitously}

BAFF is expressed primarily as a membrane bound protein but is also extensively cleaved to a soluble form $[35,36]$. Soluble BAFF levels in blood are related closely to the number of circulating B-cells and the amount of BAFF receptors available for cleavage. The normal levels of soluble BAFF in healthy adults range from 0.3 to $2.25 \mathrm{ng} / \mathrm{mL}$ in peripheral blood. The cord blood of newborns contains significantly higher concentrations of BAFF, ranging from 0.6 to $4.5 \mathrm{ng} / \mathrm{mL}$ [37].

The homotrimeric soluble form of BAFF activates BAFFR. Homotrimeric BAFF can undergo oligomerization that is required for activation of TACI [11]. The expression of BAFF is not related to a single tissue or a specific group of cells. BAFF is expressed on the surface of human myeloid lineage cells (monocytes), primary and secondary lymphoid organs (spleen, bone marrow, and lymph nodes), and various tissues that do not possess primary immune functions (e.g., low expression levels in heart and pancreas) [38]. Moreover, expression of BAFF and its receptors was confirmed in human adipose tissue cultures [17]. In a mouse model, BAFF expression was upregulated during adipocyte differentiation and under proinflammatory conditions (treatment with TNF- $\alpha$ ) [39]. BAFF also negatively affects insulin sensitivity in murine visceral adipose tissue [40]. In light of these findings, BAFF, being a cytokine and member of the adipokine family, is considered an important player in many pathophysiological conditions, including inflammation, autoimmune disorders, primary immunodeficiencies [39, 41, 42], obesity, and diabetes $[40,43,44]$. Along with its connection to the apoptosis regulating NF- $\kappa \mathrm{B}$ signaling pathway, the role of the BAFF ligand/receptor system in malignant diseases is steadily being elucidated $[31,45]$.

\section{Expression of BAFF Is Regulated by Interferon and Estrogen Levels}

Gamma interferon activation site (GAS) element was described in the promoter region of $B A F F$ gene in human intestinal epithelial cells leading to IFN- $\gamma$-induced expression of BAFF via activation of JAK/STAT signaling [46]. This molecular mechanism of BAFF regulation was supported by correlation of IFN- $\gamma$ and BAFF levels observed in various human immune system-related cells under physiological and malignant conditions [47-49]. Moreover, therapeutic IFN- $\beta$ administration also increases BAFF levels in vivo $[50,51]$. Hence, BAFF can be considered as a molecule that connects innate and specific immunity through its response to IFN- $\gamma$ and IFN- $\beta$ and its subsequent activation of B-cells.

Interestingly, BAFF expression is enhanced in the presence of elevated estrogen levels in mice with systemic lupus erythematosus [52] and estrogen-induced B-cell activation in lupus mice is blocked by the antiestrogenic activity of tamoxifen. Thus, estrogen-induced BAFF upregulation may 
contribute to a higher incidence of autoimmune disorders in females [53].

\section{BAFF Antiapoptotic and Proinflammatory Signaling Is Mediated by the NF- $\kappa$ B Pathway}

$\mathrm{NF}-\kappa \mathrm{B}$ is an intracellular protein complex and the central member of a vital and pivotal signaling pathway [54] that plays a key role in immunity [55] and inflammation [56]. Various studies have presented NF- $\kappa \mathrm{B}$ as an antiapoptotic and cell cycle control player in malignancies [57-59]. Owing to these qualities, the presence of inflammation and activated $\mathrm{NF}-\kappa \mathrm{B}$ signaling are risk factors in malignant transformation [60]. The molecular signaling of NF- $\kappa \mathrm{B}$ starts with stimulation of receptors for proinflammatory cytokines [56] and certain members of the TNF receptor superfamily, including BAFF-R, TACI, and BCMA $[61,62]$. BAFF-R-mediated activation of $\mathrm{NF}-\kappa \mathrm{B}$ goes through the noncanonical (alternative) signal pathway, whereas TACI and BCMA activate the canonical (classical) NF- $\kappa \mathrm{B}$ pathway [8]. NF- $\kappa \mathrm{B}$ has the ability to enhance recruitment of inflammatory cells [55] and the expression of proinflammatory cytokines such as IL-1 $\beta[63,64]$, IL-2 [65], IL-6 [66, 67], and TNF- $\alpha[68]$. Deficiency or mutations in the BAFF ligand/receptor system lead to inhibition of NF- $\kappa \mathrm{B}$, thus reducing its antiapoptotic and proinflammatory role [69-71].

\section{BAFF Is a Biomarker of Disease Progression in Multiple Myeloma}

Multiple myeloma (MM) is a malignant disease caused by aberrant proliferation of bone marrow plasma cells. Since BAFF is essential for the survival of B-cells and plays an important role in survival of plasma cells, particularly in early stages of their development, its role in the pathophysiology of multiple myeloma continues to be intensively studied [72, 73]. Serum levels of BAFF in MM patients were found to be significantly higher $(6.0 \pm 1.88 \mathrm{ng} / \mathrm{mL})$ than in healthy controls $(2.25 \pm 0.71 \mathrm{ng} / \mathrm{mL})$ in a study by Wang et al. [72] and elsewhere [74-76] and correlated with disease progression and intensity of plasma cell infiltration [76]. Patients with monoclonal gammopathy of unknown significance (MGUS) are reported to have significantly lower serum levels $(3.24 \pm 0.28 \mathrm{ng} / \mathrm{mL})$ of BAFF and BAFF-R than MM patients [72].

Pretherapeutic, soluble BAFF levels positively correlate with TNF- $\alpha$ [72], IL-6 [75, 76], and other adverse markers of disease activity such as C-reactive protein and lactate dehydrogenase in MM patients $[75,76]$. Posttreatment levels of BAFF correlate with IL-10, which also modulates apoptosis in B-cells [77], induces proliferation of MM cells [78, 79], and abolishes all-trans-retinoic acid inhibitory activity on MM cell growth [79]. Moreover, in the study of Lemancewicz et al., higher serum concentrations of BAFF predicted shorter progression-free survival [75]. Taken together, these clinical studies provide evidence of a strong correlation between $\mathrm{BAFF}$ and disease progression in MM.

\section{BAFF/BAFF-R Signaling May Prove to Be a Promising Target of Future Therapy in B-Cell Derived Malignancies}

Simultaneously with MM, the role of BAFF and its receptors was intensively studied in other B-cell derived malignancies such as certain subtypes of non-Hodgkin's lymphomas and precursor B-lineage acute lymphoblastic leukemia (BALL). Novak et al. found that BAFF levels corresponded with disease severity and clinical outcome and that elevated levels of BAFF correlated with aggressive phenotype of NHL in humans [80]. Similarly, increased BAFF expression profiles may contribute to Helicobacter pyloriindependent tumor growth in MALT lymphoma [81]. Elevated levels of BAFF were also reported in other Blineage lymphomas [82, 83], Hodgkin's lymphoma [84, 85], and B-ALL $[82,86]$. Although there is only one FDAapproved anti-BAFF antibody, belimumab, which is used exclusively in rheumatology, new anti-BAFF antibodies are currently being tested for treatment of B-cell lymphomas [87].

In another setting, targeting BAFF-R in B-ALL with a novel humanized anti-BAFF-R antibody selectively kills chemotherapy-resistant precursor B-ALL cells [88]. The anti-BAFF-R antibody also significantly stimulates natural killer cell-mediated killing and macrophage phagocytosis of human ALL cells in vitro and decreases leukemia burden in murine bone marrow and spleen. Its therapeutic effects were augmented in combination with conventional chemotherapeutics [89]. BAFF-R might represent a promising therapeutic target because its expression is much higher in leukemic B-cells compared to healthy B-cells [90].

\section{BAFF Levels Correlate with Disease Activity and Malignant Potential of Cancer Cells in Several Types of Nonhematologic Solid Tumors}

Compared to MM and B-derived malignancies, a possible pathophysiological link between BAFF and solid tumors is not as obvious; however, BAFF expression has recently been studied in many types of solid tumors [91-95]. Neuroendocrine tumors (NET) usually express numerous biologically active mediators. Serum levels of BAFF in NET patients $(1.195 \pm 0.568 \mathrm{ng} / \mathrm{mL})$ are significantly higher compared to healthy controls $(0.666 \pm 0.240 \mathrm{ng} / \mathrm{mL})$ [94]. Patients in disease progression $(1.503 \pm 0.637 \mathrm{ng} / \mathrm{mL})$ and patients with metastases $(1.391 \pm 0.724 \mathrm{ng} / \mathrm{mL})$ have higher serum BAFF levels compared to those with stable disease $(0.906 \pm$ $0.273 \mathrm{ng} / \mathrm{mL}$ ) [94].

BAFF plasma levels were further examined in solid childhood malignancies such as nephroblastoma (Wilms tumor), Ewing sarcoma, and rhabdomyosarcoma showing BAFF levels of $2.757 \pm 3.332 \mathrm{ng} / \mathrm{mL}, 4.311 \pm 4.750 \mathrm{ng} / \mathrm{mL}$, and $6.593 \pm 4.502 \mathrm{ng} / \mathrm{mL}$, respectively, and these levels were higher compared to the childhood non-Hodgkin's lymphoma subgroup $(2.376 \pm 1.560 \mathrm{ng} / \mathrm{mL})$ [95]. 


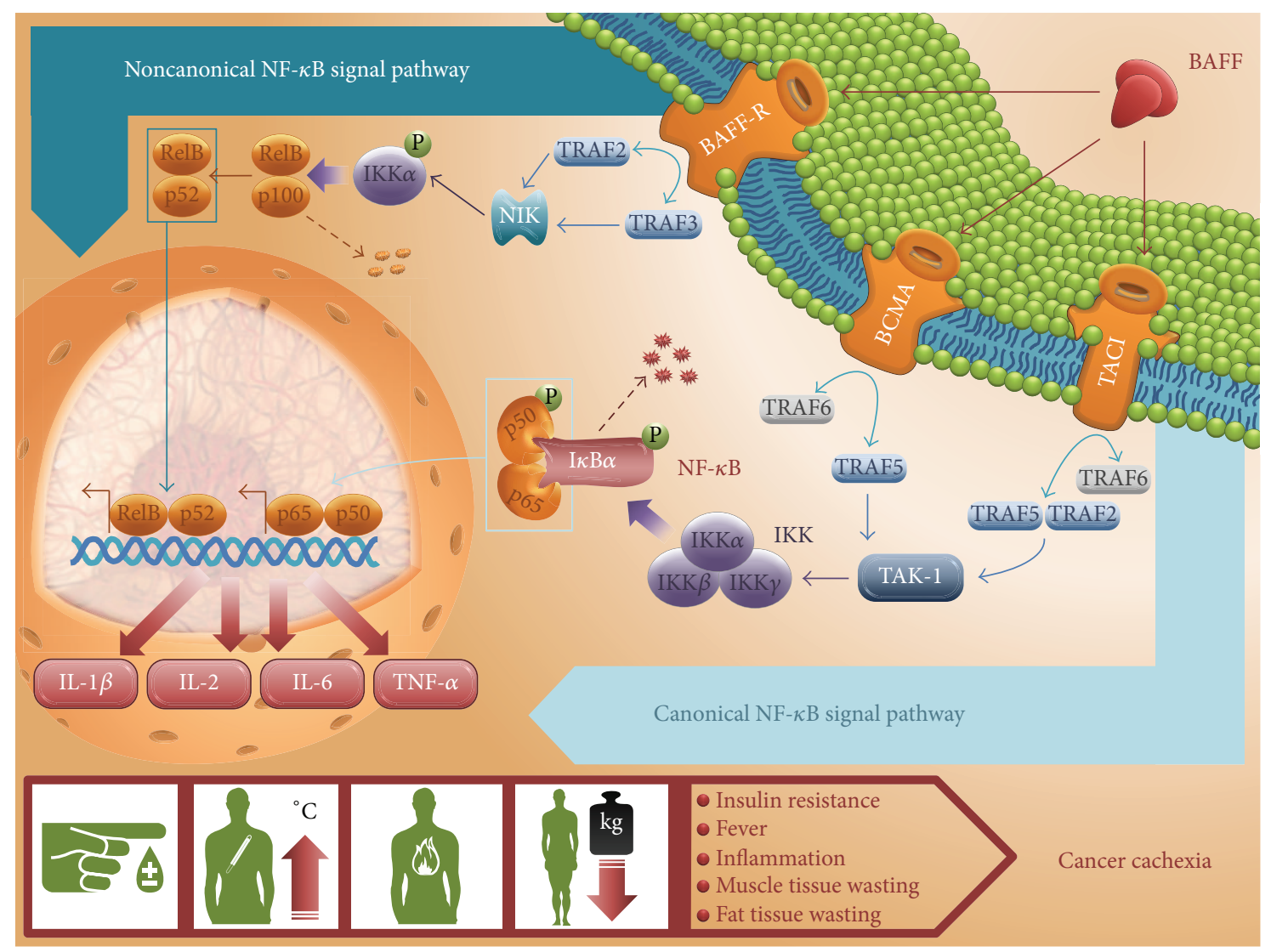

FIGURE 1: BAFF-induced activation of NF- $\kappa$ B signaling and increased expression of proinflammatory cytokines as procachectic mediators. BAFF interacts with three receptors from the TNF ligand/receptor superfamily, BAFF-R, TACI, and (with lower affinity) BCMA [8]. Upon activation, BCMA signal transduction goes through TNF receptor associated factors (TRAFs) 5 and 6 [96], whereas TACI signals through TRAF2, TRAF5, and TRAF6 [97]. TRAF2 and TRAF5 activate I $\kappa$ B kinase (IKK) via TAK-1 kinase (the canonical NF- $\kappa \mathrm{B}$ pathway) [98]. Follow-up phosphorylation of NF- $\kappa \mathrm{B}$ inhibitor alpha $(\mathrm{I} \kappa \mathrm{B} \alpha)$ induces ubiquitination of $\mathrm{I} \kappa \mathrm{B} \alpha$ and its proteasome degradation [99]. In this way, $\mathrm{I} \kappa \mathrm{B} \alpha$ is released from the phosphorylated heterodimer $\mathrm{p} 50-\mathrm{p} 65$, and $\mathrm{p} 50$-p65 then migrates to the nucleus [99]. BAFF-R signaling starts with TRAF2 and TRAF3 degradation and accumulation of NF- $\kappa$ B inducing kinase (NIK) [100]. In this noncanonical NF- $\kappa$ B pathway, NIK phosphorylates inhibitor of NF- $\kappa$ B kinase alpha (IKK $\alpha)$ [101]. IKK $\alpha$ then induces cleavage of p100 protein in the p100-RelB complex into a p52-RelB complex which acts as a modulator of nuclear gene transcription [102]. Both canonical and noncanonical NF- $\kappa B$ pathways regulate the expression of genes encoding IL-1 $\beta[63,64]$, IL-2 [65], IL-6 [66, 67], and TNF- $\alpha$ [68]. Proinflammatory cytokines participate in manifestation of cancer cachexia symptoms such as insulin resistance [103], fever [104], inflammation [105], and muscle [106-108] and fat tissue wasting $[105,109,110]$.

\section{BAFF May Contribute to Cancer Cachexia through Its Proinflammatory Properties and by Impairment of the Insulin Receptor Signaling Pathway}

Involuntary weight loss is a complication that often follows many serious symptoms such as inanition (inadequate food availability or pathophysiologic conditions substantially decreasing the desire of food), anorexia (reduced food intake caused primarily by diminished appetite with high influence of CNS mechanisms), or cachexia (metabolic disorder of increased energy expenditure leading to a greater weight loss than that caused by reduced food intake alone) [111]. Cancer cachexia is a syndrome where tumors in host organisms play important roles in degrading certain host tissues by production of catabolic mediators [112]. The exact mechanism in which malignant diseases cause cachexia is not completely understood, but there is probably a role for inflammatory cytokines, such as TNF- $\alpha$, various interleukins, and IFN- $\gamma$, as well as tumor-secreted proteolysis-inducing factor (PIF) and lipolysis mobilizing factor (LMF). Based on these findings, the ghrelin receptor agonist anamorelin hydrochloride has recently been introduced for therapy of cancer-induced cachexia (currently in phase III clinical trials for treatment of cancer cachexia in non-small-cell lung cancer) [113]. Ghrelin binds GHS receptors on T-cells and monocytes and inhibits proinflammatory cytokine expression (IL-1 $\beta$, IL- 6 , and TNF- $\alpha$ ). The mechanism of action of anamorelin in cancer cachexia is probably mediated by both a CNS-mediated increase in appetite and anti-inflammatory effects [114]. By inhibition of proinflammatory cytokines and inflammation, anamorelin acts indirectly against BAFF.

Proinflammatory cytokines target corresponding receptors on host inflammatory and tumor cells and activate 
the NF- $\kappa \mathrm{B}$ signaling pathway $[61,62]$. Activation of NF$\kappa \mathrm{B}$ leads to production of even higher amount of cytokines in a positive feedback manner [61, 115]. Binding to its receptors, BAFF enhances NF- $\kappa \mathrm{B}$ signaling that leads to increased production of proinflammatory cytokines and promotion of overall inflammation during malignancy (Figure 1) [63-68].

Another common complication arising from the altered metabolism in patients with cancer cachexia is insulin resistance [116]. Hamada et al. found that BAFF-treated mice exhibited increased blood glucose, insulin blood levels, and high expression of TNF- $\alpha$, IL- 6 , and resistin with decreased expression of adiponectin in visceral adipose tissue, suggesting an impairment in insulin receptor signaling similar to that observed in type II diabetes mellitus and metabolic syndrome. That same study confirmed reduced activation of insulin receptor substrate (IRS-1) as a response to BAFF treatment [40]. BAFF-induced insulin resistance was later confirmed in another mouse model [117]. Insulin resistance augments cancer cachexia in patients with malignancy [112, 118 ] providing another link between BAFF and the development of cancer cachexia syndrome.

\section{BAFF Signaling May Contribute to Cancer Progression and Cancer Cachexia Not Just via Its Proinflammatory Role}

BAFF may contribute to cancer progression through the amplification of proinflammatory signaling. A causative role of BAFF in cancer and cancer cachexia independent of inflammation has been difficult to substantiate; interestingly however, Koizumi et al. have shown that in vitro incubation of tumor cells isolated from pancreatic ductal adenocarcinoma (PDAC) patients with human recombinant BAFF resulted in altered phenotype with increased invasiveness and motility. Downregulation of E-cadherin mRNA and significant upregulation of vimentin and Snail mRNAs were found in these cells. BAFF-induced alteration of epithelial-mesenchymal transition- (EMT-) related genes that support precancerous formations of pancreatic intraepithelial neoplasias and PDAC itself was confirmed on BAFF-R overexpressing cell clones [91]. Thus, BAFF may promote tumorigenesis indirectly by induction of inflammation in the tumor microenvironment and directly by induction of EMT.

Similar to BAFF's involvement in cancer progression, BAFF's involvement in cancer cachexia is difficult to distinguish from its proinflammatory effects. BAFF may contribute to cancer cachexia by affecting changes in NF- $\kappa$ B pathwayinduced inflammation and through impairment of insulin sensitivity via reduction of adiponectin and possibly other adipokines maintaining glucose homeostasis.

Taken together, an increase in catabolic demands during inflammation and malignancy predispose to cancer cachexia development. BAFF may enhance the inflammatory background in cancer patients, providing a tantalizing link to involvement in cancer cachexia (Figure 2); however additional studies will be required to confirm such a link and potential avenue for therapeutic intervention.

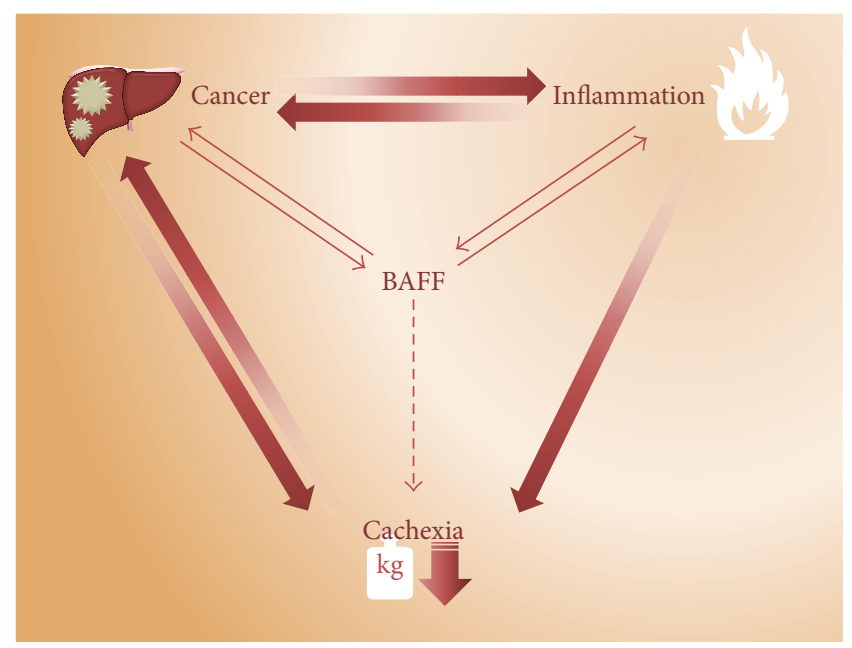

FIGURE 2: BAFF in cancer cachexia interplay. Outer arrows indicate well-described hallmarks of cancer cachexia. Cancer $\rightarrow$ inflammation: many types of cancer cells express cytokines that induce inflammation [119]. Inflammation $\rightarrow$ cancer: tumors often manifest on inflammatory background that supports transition of cells to malignant clones (e.g., hepatocellular carcinoma or PDAC as cited in the text). Cancer $\rightarrow$ cachexia: tumor tissue directly participates in the development of cancer cachexia by production of tumor specific factors like PIF and LMF [120, 121]. Cachexia $\rightarrow$ cancer: cachexia in cancer patients remains a significant cause of morbidity and mortality in cancer treatment [122]. Inflammation $\rightarrow$ cachexia: proinflammatory cytokines induce cachexia by increased catabolism with altered insulin sensitivity [119]. Inner arrows indicate established (solid line) and putative (dashed line) role of BAFF in pathophysiology of cancer cachexia. Cancer $\rightarrow$ BAFF: increased expression and serum levels of BAFF were demonstrated in many types of hematological and solid tumors making BAFF a possible new biomarker in malignancies. BAFF $\rightarrow$ cancer: BAFF has been found to augment manifestation of lymphoma and the formation of epithelial-mesenchymal transitions and pancreatic intraepithelial neoplasias. These events precede PDAC. (1) A TNFindependent role of BAFF in the pathophysiology of lymphomas was demonstrated in BAFF-Tg $\mathrm{TNF}^{-/-}$mice. More than 35\% of BAFF$\mathrm{Tg} \mathrm{TNF}^{-/-}$mice had occurrence of various types of lymphomas within 1 year [123]. (2) BAFF-induced alteration of the epithelialmesenchymal transition- (EMT-) related genes that support precancerous formation of pancreatic intraepithelial neoplasias and PDAC was confirmed on BAFF-R overexpressing cell clones [91]. Inflammation $\rightarrow$ BAFF: BAFF is produced by several proinflammatory cells. BAFF $\rightarrow$ inflammation: BAFF induces expression of proinflammatory cytokines by activation of NF- $\kappa$ B [124]. BAFF $\rightarrow$ cachexia: BAFF induces insulin resistance $[40,117]$ which has been associated with cancer cachexia $[116,118]$.

\section{Conflict of Interests}

The authors declare that there is no conflict of interests regarding the publication of this paper.

\section{Acknowledgments}

This work was supported by Czech Ministry of Health, DRO (MMCI, 00209805), European Regional Development 
Fund, and the State Budget of the Czech Republic for Regional Centre of Applied Molecular Oncology (RECAMO, CZ.1.05/2.1.00/03.0101), by MEYS-NPS I-LO1413, and by Large Infrastructure Projects of Czech Ministry of Education, Youth and Sports (ACIU, LM2011017). The authors thank Eva Rihackova, student of veterinary medicine in Brno, for her help with artwork for this paper.

\section{References}

[1] H.-B. Shu, W.-H. Hu, and H. Johnson, "TALL-1 is a novel member of the TNF family that is down-regulated by mitogens," Journal of Leukocyte Biology, vol. 65, no. 5, pp. 680-683, 1999.

[2] B. B. Aggarwal, S. C. Gupta, and J. H. Kim, "Historical perspectives on tumor necrosis factor and its superfamily: 25 years later, a golden journey," Blood, vol. 119, no. 3, pp. 651-665, 2012.

[3] F. Mackay and J. L. Browning, "BAFF: a fundamental survival factor for B cells," Nature Reviews. Immunology, vol. 2, no. 7, pp. 465-475, 2002.

[4] B. Schiemann, J. L. Gommerman, K. Vora et al., "An essential role for BAFF in the normal development of $\mathrm{B}$ cells through a BCMA-independent pathway," Science, vol. 293, no. 5537, pp. 2111-2114, 2001.

[5] J. A. Gross, S. R. Dillon, S. Mudri et al., “TACI-Ig neutralizes molecules critical for B cell development and autoimmune disease: impaired B cell maturation in mice lacking BLyS," Immunity, vol. 15, no. 2, pp. 289-302, 2001.

[6] E. Castigli, S. A. Wilson, S. Scott et al., "TACI and BAFF-R mediate isotype switching in B cells," The Journal of Experimental Medicine, vol. 201, no. 1, pp. 35-39, 2005.

[7] J. E. Stadanlick, M. Kaileh, F. G. Karnell et al., "Tonic B cell antigen receptor signals supply an NF- $\kappa \mathrm{B}$ substrate for prosurvival BLyS signaling," Nature Immunology, vol. 9, no. 12, pp. 1379-1387, 2008.

[8] C. Bossen and P. Schneider, "BAFF, APRIL and their receptors: structure, function and signaling," Seminars in Immunology, vol. 18, no. 5, pp. 263-275, 2006.

[9] J. S. Thompson, S. A. Bixler, F. Qian et al., "BAFF-R, a newly identified TNF receptor that specifically interacts with BAFF", Science, vol. 293, no. 5537, pp. 2108-2111, 2001.

[10] M. Yan, J. R. Brady, B. Chan et al., "Identification of a novel receptor for $\mathrm{B}$ lymphocyte stimulator that is mutated in a mouse strain with severe B cell deficiency," Current Biology, vol. 11, no. 19, pp. 1547-1552, 2001.

[11] C. Bossen, T. G. Cachero, A. Tardivel et al., "TACI, unlike BAFF$\mathrm{R}$, is solely activated by oligomeric BAFF and APRIL to support survival of activated B cells and plasmablasts," Blood, vol. 111, no. 3, pp. 1004-1012, 2008.

[12] D. Seshasayee, P. Valdez, M. Yan et al., "Loss of TACI causes fatal lymphoproliferation and autoimmunity, establishing TACI as an inhibitory BLyS receptor," Immunity, vol. 18, no. 2, pp. 279288, 2003.

[13] Johns Hopkins University, Online Mendelian Inheritance in Man, OMIM, Johns Hopkins University, Baltimore, Md, USA, 2012, http://omim.org/.

[14] B. P. Deng, Y. Zhang, Q. J. Wang et al., "Soluble BAFF-R produced by decidual stromal cells plays an inhibitory role in monocytes and macrophages," Reproductive Biomedicine Online, vol. 24, no. 6, pp. 654-663, 2012.
[15] S. J. Rodig, A. Shahsafaei, B. Li, C. R. Mackay, and D. M. Dorfman, "BAFF-R, the major B cell-activating factor receptor, is expressed on most mature B cells and B-cell lymphoproliferative disorders," Human Pathology, vol. 36, no. 10, pp. 1113-1119, 2005.

[16] Q. Ye, L. Wang, A. D. Wells et al., "BAFF binding to T cell-expressed BAFF-R costimulates $\mathrm{T}$ cell proliferation and alloresponses," European Journal of Immunology, vol. 34, no. 10, pp. 2750-2759, 2004.

[17] V.-I. Alexaki, G. Notas, V. Pelekanou et al., "Adipocytes as immune cells: differential expression of TWEAK, BAFF, and APRIL and their receptors (Fn14, BAFF-R, TACI, and BCMA) at different stages of normal and pathological adipose tissue development," The Journal of Immunology, vol. 183, no. 9, pp. 5948-5956, 2009.

[18] L. Fu, Y.-C. Lin-Lee, L. V. Pham, A. T. Tamayo, L. C. Yoshimura, and R. J. Ford, "BAFF-R promotes cell proliferation and survival through interaction with IKK $\beta$ and NF- $\kappa \mathrm{B} / \mathrm{c}$-Rel in the nucleus of normal and neoplastic B-lymphoid cells," Blood, vol. 113, no. 19, pp. 4627-4636, 2009.

[19] R. H. Carter, H. Zhao, X. Liu et al., "Expression and occupancy of BAFF-R on B cells in systemic lupus erythematosus," Arthritis and Rheumatism, vol. 52, no. 12, pp. 3943-3954, 2005.

[20] J.-O. Pers, C. Daridon, V. Devauchelle et al., "BAFF overexpression is associated with autoantibody production in autoimmune diseases," Annals of the New York Academy of Sciences, vol. 1050, pp. 34-39, 2005.

[21] Johns Hopkins University, Online Mendelian Inheritance in Man, OMIM, Johns Hopkins University, Baltimore, Md, USA, 2011, http://omim.org/.

[22] R. Wang, N. Ma, Y. Guo et al., "Identify the key amino acid of BAFF binding with TACI," Cellular Immunology, vol. 284, no. 1-2, pp. 84-90, 2013.

[23] H. Wang, S. A. Marsters, T. Baker et al., "TACI-ligand interactions are required for $\mathrm{T}$ cell activation and collagen-induced arthritis in mice," Nature Immunology, vol. 2, no. 7, pp. 632-637, 2001.

[24] M. Yan, S. A. Marsters, I. S. Grewal, H. Wang, A. Ashkenazi, and V. M. Dixit, "Identification of a receptor for BLyS demonstrates a crucial role in humoral immunity," Nature Immunology, vol. 1, no. 1, pp. 37-41, 2000.

[25] G. Yu, T. Boone, J. Delaney et al., "APRIL and TALL-I and receptor BCMA and TACI: system for regulating humoral immunity," Nature Immunology, vol. 1, no. 3, pp. 252-256, 2000.

[26] A. E. J. Poodt, G. J. A. Driessen, A. de Klein, J. J. M. van Dongen, M. van Der Burg, and E. de Vries, “TACI mutations and disease susceptibility in patients with common variable immunodeficiency," Clinical and Experimental Immunology, vol. 156, no. 1, pp. 35-39, 2009.

[27] U. Salzer, H. M. Chapel, A. D. B. Webster et al., "Mutations in TNFRSF13B encoding TACI are associated with common variable immunodeficiency in humans," Nature Genetics, vol. 37, no. 8, pp. 820-828, 2005.

[28] Online Mendelian Inheritance in Man, OMIM, Johns Hopkins University, Baltimore, Md, USA, MIM Number: 109545, 2012, http://omim.org/.

[29] B. P. O'Connor, V. S. Raman, L. D. Erickson et al., "BCMA is essential for the survival of long-lived bone marrow plasma cells," Journal of Experimental Medicine, vol. 199, no. 1, pp. 91-97, 2004.

[30] A. J. Novak, J. R. Darce, B. K. Arendt et al., "Expression of BCMA, TACI, and BAFF-R in multiple myeloma: a mechanism 
for growth and survival," Blood, vol. 103, no. 2, pp. 689-694, 2004.

[31] J. Moreaux, E. Legouffe, E. Jourdan et al., "BAFF and APRIL protect myeloma cells from apoptosis induced by interleukin 6 deprivation and dexamethasone," Blood, vol. 103, no. 8, pp. 3148-3157, 2004.

[32] R. O. Carpenter, M. O. Evbuomwan, S. Pittaluga et al., "B-cell maturation antigen is a promising target for adoptive T-cell therapy of multiple myeloma," Clinical Cancer Research, vol. 19, no. 8, pp. 2048-2060, 2013.

[33] Y. Sasaki, E. Derudder, E. Hobeika et al., "Canonical NFkappaB activity, dispensable for B cell development, replaces BAFF-receptor signals and promotes B cell proliferation upon activation," Immunity, vol. 24, no. 6, pp. 729-739, 2006.

[34] J.-I. Inoue, T. Ishida, N. Tsukamoto et al., “Tumor necrosis factor receptor-associated factor (TRAF) family: adapter proteins that mediate cytokine signaling," Experimental Cell Research, vol. 254, no. 1, pp. 14-24, 2000.

[35] P. Schneider, F. Mackay, V. Steiner et al., "BAFF, a novel ligand of the tumor necrosis factor family, stimulates B cell growth," Journal of Experimental Medicine, vol. 189, no. 11, pp. 1747-1756, 1999.

[36] B. Nardelli, O. Belvedere, V. Roschke et al., "Synthesis and release of B-lymphocyte stimulator from myeloid cells," Blood, vol. 97, no. 1, pp. 198-204, 2001.

[37] M. Kreuzaler, M. Rauch, U. Salzer et al., "Soluble BAFF levels inversely correlate with peripheral B cell numbers and the expression of BAFF receptors," Journal of Immunology, vol. 188, no. 1, pp. 497-503, 2012.

[38] P. A. Moore, O. Belvedere, A. Orr et al., "BLyS: member of the tumor necrosis factor family and B lymphocyte stimulator," Science, vol. 285, no. 5425, pp. 260-263, 1999.

[39] Y.-H. Kim, B.-H. Choi, H.-G. Cheon, and M.-S. Do, "B cell activation factor (BAFF) is a novel adipokine that links obesity and inflammation," Experimental and Molecular Medicine, vol. 41, no. 3, pp. 208-216, 2009.

[40] M. Hamada, M. Abe, T. Miyake et al., "B cell-activating factor controls the production of adipokines and induces insulin resistance," Obesity, vol. 19, no. 10, pp. 1915-1922, 2011.

[41] A. K. Knight, L. Radigan, T. Marron, A. Langs, L. Zhang, and C. Cunningham-Rundles, "High serum levels of BAFF, APRIL, and TACI in common variable immunodeficiency," Clinical Immunology, vol. 124, no. 2, pp. 182-189, 2007.

[42] A. Davidson, "Targeting BAFF in autoimmunity," Current Opinion in Immunology, vol. 22, no. 6, pp. 732-739, 2010.

[43] R. S. Ahima and S. Y. Osei, "Adipokines in obesity," Frontiers of Hormone Research, vol. 36, pp. 182-197, 2008.

[44] G. Ferraccioli and E. Gremese, "Adiposity, joint and systemic inflammation: the additional risk of having a metabolic syndrome in rheumatoid arthritis," Swiss Medical Weekly, vol. 141, Article ID w13211, 2011.

[45] H. Xu, X. He, Y. Zhu, T. Yan, H. Ma, and X. Zhang, "Abnormally high expression of BAFF on T lymphocytes from lung cancerassociated pleural effusions and its potent anti-tumor effect," Acta Biochimica et Biophysica Sinica, vol. 39, no. 12, pp. 964-973, 2007.

[46] S.-J. Woo, J. Im, J. H. Jeon et al., "Induction of BAFF expression by IFN- $\gamma$ via JAK/STAT signaling pathways in human intestinal epithelial cells," Journal of Leukocyte Biology, vol. 93, no. 3, pp. 363-368, 2013.
[47] L. Zhou, R. Zhong, W. Hao et al., "Interleukin-10 and interferon$\gamma$ up-regulate the expression of B-cell activating factor in cultured human promyelocytic leukemia cells," Experimental and Molecular Pathology, vol. 87, no. 1, pp. 54-58, 2009.

[48] M. Ittah, C. Miceli-Richard, J.-E. Gottenberg et al., "B cellactivating factor of the tumor necrosis factor family (BAFF) is expressed under stimulation by interferon in salivary gland epithelial cells in primary Sjögren's syndrome," Arthritis Research and Therapy, vol. 8, no. 2, article R51, 2006.

[49] P. Scapini, F. Bazzoni, and M. A. Cassatella, "Regulation of Bcell-activating factor (BAFF)/B lymphocyte stimulator (BLyS) expression in human neutrophils," Immunology Letters, vol. 116, no. 1, pp. 1-6, 2008.

[50] K. S. Gandhi, F. C. McKay, S. D. Schibeci et al., "BAFF is a biological response marker to IFN- $\beta$ treatment in multiple sclerosis," Journal of Interferon and Cytokine Research, vol. 28, no. 9, pp. 529-539, 2008.

[51] C. J. Hedegaard, F. Sellebjerg, M. Krakauer, D. Hesse, K. Bendtzen, and C. H. Nielsen, "Interferon-beta increases systemic BAFF levels in multiple sclerosis without increasing autoantibody production," Multiple Sclerosis, vol. 17, no. 5, pp. 567-577, 2011.

[52] R. Panchanathan and D. Choubey, "Murine BAFF expression is up-regulated by estrogen and interferons: implications for sex bias in the development of autoimmunity," Molecular Immunology, vol. 53, no. 1-2, pp. 15-23, 2013.

[53] E. Peeva, J. Venkatesh, and B. Diamond, "Tamoxifen blocks estrogen-induced B cell maturation but not survival," Journal of Immunology, vol. 175, no. 3, pp. 1415-1423, 2005.

[54] T. D. Gilmore, "Introduction to NF- ${ }_{\kappa} \mathrm{B}$ : players, pathways, perspectives," Oncogene, vol. 25, no. 51, pp. 6680-6684, 2006.

[55] M. S. Hayden, A. P. West, and S. Ghosh, "NF- $\kappa$ B and the immune response," Oncogene, vol. 25, no. 51, pp. 6758-6780, 2006.

[56] P. P. Tak and G. S. Firestein, "NF- $\kappa$ B: a key role in inflammatory diseases," The Journal of Clinical Investigation, vol. 107, no. 1, pp. 7-11, 2001.

[57] J. M. Hildebrand, Z. Luo, M. K. Manske et al., "A BAFF-R mutation associated with non-Hodgkin lymphoma alters TRAF recruitment and reveals new insights into BAFF-R signaling," Journal of Experimental Medicine, vol. 207, no. 12, pp. 25692579, 2010.

[58] X. Shen, W. Zhu, X. Zhang, G. Xu, and S. Ju, "A role of both NFkappaB pathways in expression and transcription regulation of BAFF-R gene in multiple myeloma cells," Molecular and Cellular Biochemistry, vol. 357, no. 1-2, pp. 21-30, 2011.

[59] G. Brandi, M. A. Pantaleo, G. Biasco, and P. Paterini, "Activated NF-kB in colorectal cancer: predictive or prognostic factor?" Journal of Clinical Oncology, vol. 26, no. 8, pp. 1388-1389, 2008.

[60] E. Pikarsky, R. M. Porat, I. Stein et al., "NF- $\kappa$ B functions as a tumour promoter in inflammation-associated cancer," Nature, vol. 431, no. 7007, pp. 461-466, 2004.

[61] B. Baumann, J. Seufert, F. Jakob et al., "Activation of NF$\kappa \mathrm{B}$ signalling and TNF $\alpha$-expression in THP-1 macrophages by TiAlV-and polyethylene-wear particles," Journal of Orthopaedic Research, vol. 23, no. 6, pp. 1241-1248, 2005.

[62] J. F. Treml, Y. Hao, J. E. Stadanlick, and M. P. Cancro, "The BLyS family: toward a molecular understanding of B cell homeostasis," Cell Biochemistry and Biophysics, vol. 53, no. 1, pp. $1-16,2009$. 
[63] J. Hiscott, J. Marois, J. Garoufalis et al., "Characterization of a functional NF-kappa B site in the human interleukin 1 beta promoter: evidence for a positive autoregulatory loop," Molecular and Cellular Biology, vol. 13, no. 10, pp. 6231-6240, 1993.

[64] J. P. Cogswell, M. M. Godlevski, G. B. Wisely et al., "NF$\kappa \mathrm{B}$ regulates IL- $1 \beta$ transcription through a consensus NF- $\kappa \mathrm{B}$ binding site and a nonconsensus CRE-like site," Journal of Immunology, vol. 153, no. 2, pp. 712-723, 1994.

[65] M. Los, H. Schenk, K. Hexel, P. A. Baeuerle, W. Droge, and K. Schulze-Osthoff, "IL-2 gene expression and NF- $\kappa$ B activation through $\mathrm{CD} 28$ requires reactive oxygen production by 5lipoxygenase," EMBO Journal, vol. 14, no. 15, pp. 3731-3740, 1995.

[66] W. Xiao, D. R. Hodge, L. Wang, X. Yang, X. Zhang, and W. L. Farrar, "NF- $\kappa$ B activates IL-6 expression through cooperation with c-Jun and IL6-AP1 site, but is independent of its IL6-NF $\kappa$ B regulatory site in autocrine human multiple myeloma cells," Cancer Biology \& Therapy, vol. 3, no. 10, pp. 1007-1017, 2004.

[67] T. A. Libermann and D. Baltimore, "Activation of interleukin6 gene expression through the NF- $\kappa \mathrm{B}$ transcription factor," Molecular and Cellular Biology, vol. 10, no. 5, pp. 2327-2334, 1990.

[68] R. Crinelli, A. Antonelli, M. Bianchi et al., "Selective inhibition of NF- $\kappa$ B activation and TNF-alpha production in macrophages by red blood cell-mediated delivery of dexamethasone," Blood Cells, Molecules \& Diseases, vol. 26, no. 3, pp. 211-222, 2000.

[69] C. Fan, J. Yang, and J. F. Engelhardt, “Temporal pattern of NF $\kappa$ B activation influences apoptotic cell fate in a stimuli-dependent fashion," Journal of Cell Science, vol. 115, no. 24, pp. 4843-4853, 2002.

[70] B. Kaltschmidt, C. Kaltschmidt, T. G. Hofmann, S. P. Hehner, W. Dröge, and M. L. Schmitz, "The pro- or anti-apoptotic function of NF- $\kappa \mathrm{B}$ is determined by the nature of the apoptotic stimulus," European Journal of Biochemistry, vol. 267, no. 12, pp. 3828-3835, 2000.

[71] C.-Y. Wang, M. W. Mayo, R. G. Korneluk, D. V. Goeddel, and A. S. Baldwin Jr., "NF-kappaB antiapoptosis: induction of TRAF1 and TRAF2 and c-IAP1 and c-IAP2 to suppress caspase8 activation," Science, vol. 281, no. 5383, pp. 1680-1683, 1998.

[72] P. Wang, L. Qian, X. Yuan et al., "BlyS: a potential hallmark of multiple myeloma," Frontiers in Bioscience, vol. 18, no. 1, pp. 324331, 2013.

[73] V. T. Chu, A. Beller, T. T. N. Nguyen, G. Steinhauser, and C. Berek, "The long-term survival of plasma cells," Scandinavian Journal of Immunology, vol. 73, no. 6, pp. 508-511, 2011.

[74] L. Bolkun, D. Lemancewicz, E. Jablonska et al., "BAFF and APRIL as TNF superfamily molecules and angiogenesis parallel progression of human multiple myeloma," Annals of Hematology, vol. 93, no. 4, pp. 635-644, 2014.

[75] D. Lemancewicz, L. Bolkun, E. Jablonska et al., "Evaluation of TNF superfamily molecules in multiple myeloma patients: correlation with biological and clinical features," Leukemia Research, vol. 37, no. 9, pp. 1089-1093, 2013.

[76] M. G. Alexandrakis, P. Roussou, C. A. Pappa et al., "Relationship between circulating BAFF serum levels with proliferating markers in patients with multiple myeloma," BioMed Research International, vol. 2013, Article ID 389579, 6 pages, 2013.

[77] K. Itoh and S. Hirohata, "The role of IL-10 in human B cell activation, proliferation, and differentiation," The Journal of Immunology, vol. 154, no. 9, pp. 4341-4350, 1995.
[78] E. Kovacs, "Interleukin-6 leads to interleukin-10 production in several human multiple myeloma cell lines. Does interleukin10 enhance the proliferation of these cells?" Leukemia Research, vol. 34, no. 7, pp. 912-916, 2010.

[79] T. Otsuki, K. Yata, H. Sakaguchi et al., "IL-10 in myeloma cells," Leukemia and Lymphoma, vol. 43, no. 5, pp. 969-974, 2002.

[80] A. J. Novak, D. M. Grote, M. Stenson et al., "Expression of BLyS and its receptors in B-cell non-Hodgkin lymphoma: correlation with disease activity and patient outcome," Blood, vol. 104, no. 8, pp. 2247-2253, 2004.

[81] S.-H. Kuo, P.-Y. Yeh, L.-T. Chen et al., "Overexpression of B cell activating factor of TNF family (BAFF) is associated with Helicobacter pylori independent growth of gastric diffuse large B-cell lymphoma with histologic evidence of MALT lymphoma," Blood, vol. 112, no. 7, pp. 2927-2934, 2008.

[82] J. Bienertova-Vasku, P. Bienert, D. Kodytkova et al., "BAFF levels are elevated in paediatric patients with acute lymphoblastic leukaemia compared to other B-lineage neoplasms," Journal of Hematology, vol. 1, no. 1, pp. 20-22, 2012.

[83] S. Yang, J.-Y. Li, and W. Xu, "Role of BAFF/BAFF-R axis in B-cell non-Hodgkin lymphoma," Critical Reviews in Oncology/Hematology, vol. 91, no. 2, pp. 113-122, 2014.

[84] Y. Oki, G. V. Georgakis, T.-S. Migone, L. W. Kwak, and A. Younes, "Prognostic significance of serum B-lymphocyte stimulator level in Hodgkin's lymphoma," Haematologica, vol. 92, no. 2, pp. 269-270, 2007.

[85] C. Tecchio, G. Nadali, P. Scapini et al., "High serum levels of Blymphocyte stimulator are associated with clinical-pathological features and outcome in classical Hodgkin lymphoma," British Journal of Haematology, vol. 137, no. 6, pp. 553-559, 2007.

[86] K. Onda, K. Iijima, Y. U. Katagiri et al., "Differential effects of BAFF on B cell precursor acute lymphoblastic leukemia and Burkitt lymphoma," International Journal of Hematology, vol. 91, no. 5, pp. 808-819, 2010.

[87] W. Wu, S. Li, W. Zhang, G. Ren, and Q. Dong, "A novel $\mathrm{VHH}$ antibody targeting the B cell-activating factor for B-cell lymphoma," International Journal of Molecular Sciences, vol. 15, no. 6, pp. 9481-9496, 2014.

[88] S. Maia, M. Pelletier, J. Ding et al., "Aberrant expression of functional baff-system receptors by malignant b-cell precursors impacts leukemia cell survival," PLoS ONE, vol. 6, no. 6, Article ID e20787, 2011.

[89] R. Parameswaran, M. Lim, F. Fei et al., "Effector-mediated eradication of precursor B acute lymphoblastic leukemia with a novel Fc-engineered monoclonal antibody targeting the BAFFR," Molecular Cancer Therapeutics, vol. 13, no. 6, pp. 1567-1577, 2014.

[90] R. Parameswaran, M. Müschen, Y.-M. Kim, J. Groffen, and N. Heisterkamp, "A functional receptor for B-cell-activating factor is expressed on human acute lymphoblastic leukemias," Cancer Research, vol. 70, no. 11, pp. 4346-4356, 2010.

[91] M. Koizumi, Y. Hiasa, T. Kumagi et al., "Increased B cellactivating factor promotes tumor invasion and metastasis in human pancreatic cancer," PLoS ONE, vol. 8, no. 8, Article ID e71367, 2013.

[92] V. Pelekanou, M. Kampa, M. Kafousi et al., "Expression of TNF-superfamily members BAFF and APRIL in breast cancer: immunohistochemical study in 52 invasive ductal breast carcinomas," BMC Cancer, vol. 8, article 76, 2008.

[93] V. Pelekanou, G. Notas, M. Kampa et al., "BAFF, APRIL, TWEAK, BCMA, TACI and Fn14 proteins are related to 
human glioma tumor grade: immunohistochemistry and public microarray data meta-analysis," PLoS ONE, vol. 8, no. 12, Article ID e83250, 2013.

[94] M. Fabris, E. Tonutti, C. Panighel et al., "The role of Blymphocyte stimulator in neuroendocrine tumors: correlation with tumor differentiation, disease status and the presence of metastases," Immunology, Endocrine and Metabolic Agents in Medicinal Chemistry, vol. 11, no. 4, pp. 306-314, 2011.

[95] J. Bienertova-Vasku, A. Lungova, P. Bienert et al., "Circulating levels of B-cell activating factor in paediatric patients with malignancy with or without cancer-related cachexia," Klinicka Onkologie, vol. 25, no. 2, pp. S58-S63, 2012.

[96] H.-B. Shu and H. Johnson, "B cell maturation protein is a receptor for the tumor necrosis factor family member TALL1," Proceedings of the National Academy of Sciences of the United States of America, vol. 97, no. 16, pp. 9156-9161, 2000.

[97] X.-Z. Xia, J. Treanor, G. Senaldi et al., "TACI is a TRAFinteracting receptor for TALL-1, a tumor necrosis factor family member involved in B cell regulation," Journal of Experimental Medicine, vol. 192, no. 1, pp. 137-143, 2000.

[98] H. Sakurai, S. Suzuki, N. Kawasaki et al., "Tumor necrosis factor- $\alpha$-induced IKK phosphorylation of NF- $\kappa \mathrm{B}$ p 65 on serine 536 is mediated through the TRAF2, TRAF5, and TAK1 signaling pathway," Journal of Biological Chemistry, vol. 278, no. 38, pp. 36916-36923, 2003.

[99] P. Viatour, M.-P. Merville, V. Bours, and A. Chariot, "Phosphorylation of NF- $\kappa \mathrm{B}$ and $\mathrm{I} \kappa \mathrm{B}$ proteins: implications in cancer and inflammation," Trends in Biochemical Sciences, vol. 30, no. 1, pp. 43-52, 2005.

[100] S. C. Sun, "Controlling the fate of NIK: a central stage in noncanonical NF-kappaB signaling," Science Signaling, vol. 3, no. 123, article pe18, 2010.

[101] U. Senftleben, Y. Cao, G. Xiao et al., "Activation by IKK $\alpha$ of a second, evolutionary conserved, NF- $\kappa \mathrm{B}$ signaling pathway," Science, vol. 293, no. 5534, pp. 1495-1499, 2001.

[102] N. J. Solan, H. Miyoshi, E. M. Carmona, G. D. Bren, and C. V. Paya, "RelB cellular regulation and transcriptional activity are regulated by p100," The Journal of Biological Chemistry, vol. 277, no. 2, pp. 1405-1418, 2002.

[103] G. S. Hotamisligil, "Mechanisms of TNF- $\alpha$-induced insulin resistance," Experimental and Clinical Endocrinology and Diabetes, vol. 107, no. 2, pp. 119-125, 1999.

[104] A. K. Sundgren-Andersson, P. Ostlund, and T. Bartfai, "IL-6 is essential in TNF- $\alpha$-induced fever," The American Journal of Physiology-Regulatory Integrative and Comparative Physiology, vol. 275, no. 6, pp. R2028-R2034, 1998.

[105] K. J. Tracey, H. Wei, K. R. Manogue et al., "Cachectin/tumor necrosis factor induces cachexia, anemia, and inflammation," The Journal of Experimental Medicine, vol. 167, no. 3, pp. 1211$1227,1988$.

[106] J. A. Carson and K. A. Baltgalvis, "Interleukin 6 as a key regulator of muscle mass during cachexia," Exercise and Sport Sciences Reviews, vol. 38, no. 4, pp. 168-176, 2010.

[107] F. Haddad, F. Zaldivar, D. M. Cooper, and G. R. Adams, "IL-6induced skeletal muscle atrophy," Journal of Applied Physiology, vol. 98, no. 3, pp. 911-917, 2005.

[108] O. Zamir, P. O. Hasselgren, T. Higashiguchi, J. A. Frederick, and J. E. Fischer, "Tumour necrosis factor (TNF) and interleukin1 (IL-1) induce muscle proteolysis through different mechanisms," Mediators of Inflammation, vol. 1, no. 4, pp. 247-250, 1992.
[109] P. Gulati, "Janeway's immunobiology, 7th edition by kenneth murphy, paul travers, and mark walport," Biochemistry and Molecular Biology Education, vol. 37, no. 2, pp. 134-134, 2009.

[110] A. Oliff, D. Defeo-Jones, M. Boyer et al., "Tumors secreting human TNF/cachectin induce cachexia in mice," Cell, vol. 50, no. 4, pp. 555-563, 1987.

[111] A. C. Guyton and J. E. Hall, Textbook of Medical Physiology, Elsevier Science Health Science Division, Philadelphia, Pa, USA, 12 edition, 2012.

[112] R. J. E. Skipworth, G. D. Stewart, C. H. C. Dejong, T. Preston, and K. C. H. Fearon, "Pathophysiology of cancer cachexia: much more than host-tumour interaction?" Clinical Nutrition, vol. 26, no. 6, pp. 667-676, 2007.

[113] S. L. Dickson, E. Egecioglu, S. Landgren, K. P. Skibicka, J. A. Engel, and E. Jerlhag, "The role of the central ghrelin system in reward from food and chemical drugs," Molecular and Cellular Endocrinology, vol. 340, no. 1, pp. 80-87, 2011.

[114] V. D. Dixit, E. M. Schaffer, R. S. Pyle et al., "Ghrelin inhibits leptin- and activation-induced proinflammatory cytokine expression by human monocytes and T cells," The Journal of Clinical Investigation, vol. 114, no. 1, pp. 57-66, 2004.

[115] M. A. Brach, H. J. Gruss, D. Riedel, R. Mertelsmann, and F. Herrmann, "Activation of NF- $\kappa$ B by interleukin 2 in human blood monocytes," Cell Growth \& Differentiation, vol. 3, no. 7, pp. 421-427, 1992.

[116] J. A. Tayek, "A review of cancer cachexia and abnormal glucose metabolism in humans with cancer," Journal of the American College of Nutrition, vol. 11, no. 4, pp. 445-456, 1992.

[117] K. Kawasaki, M. Abe, F. Tada et al., "Blockade of B-cellactivating factor signaling enhances hepatic steatosis induced by a high-fat diet and improves insulin sensitivity," Laboratory Investigation, vol. 93, no. 3, pp. 311-321, 2013.

[118] M. L. Asp, M. Tian, A. A. Wendel, and M. A. Belury, "Evidence for the contribution of insulin resistance to the development of cachexia in tumor-bearing mice," International Journal of Cancer, vol. 126, no. 3, pp. 756-763, 2010.

[119] M. Tsoli and G. Robertson, "Cancer cachexia: malignant inflammation, tumorkines, and metabolic mayhem," Trends in Endocrinology \& Metabolism, vol. 24, no. 4, pp. 174-183, 2013.

[120] R. Cabal-Manzano, P. Bhargava, A. Torres-Duarte, J. Marshall, P. Bhargava, and I. W. Wainer, "Proteolysis-inducing factor is expressed in tumours of patients with gastrointestinal cancers and correlates with weight loss," British Journal of Cancer, vol. 84, no. 12, pp. 1599-1601, 2001.

[121] S. Khan and M. J. Tisdale, "Catabolism of adipose tissue by a tumour-produced lipid-mobilising factor," International Journal of Cancer, vol. 80, no. 3, pp. 444-447, 1999.

[122] N. P. Gullett, V. C. Mazurak, G. Hebbar, and T. R. Ziegler, "Nutritional interventions for cancer-induced cachexia," Current Problems in Cancer, vol. 35, no. 2, pp. 58-90, 2011.

[123] M. Batten, C. Fletcher, L. G. Ng et al., "TNF deficiency fails to protect BAFF transgenic mice against autoimmunity and reveals a predisposition to B cell lymphoma," The Journal of Immunology, vol. 172, no. 2, pp. 812-822, 2004.

[124] S. K. Chang, B. K. Arendt, J. R. Darce, X. Wu, and D. F. Jelinek, "A role for BLyS in the activation of innate immune cells," Blood, vol. 108, no. 8, pp. 2687-2694, 2006. 


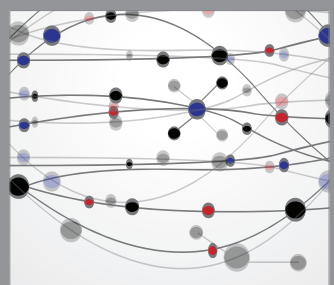

The Scientific World Journal
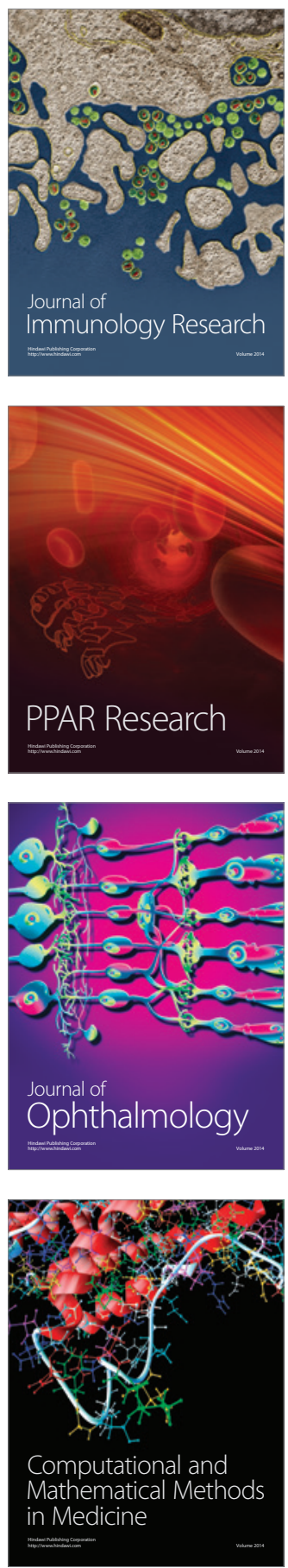

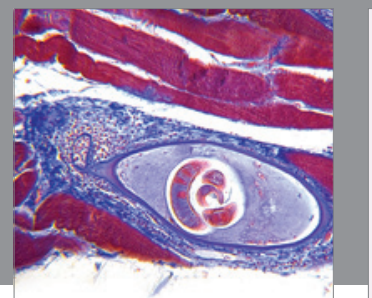

Gastroenterology

Research and Practice
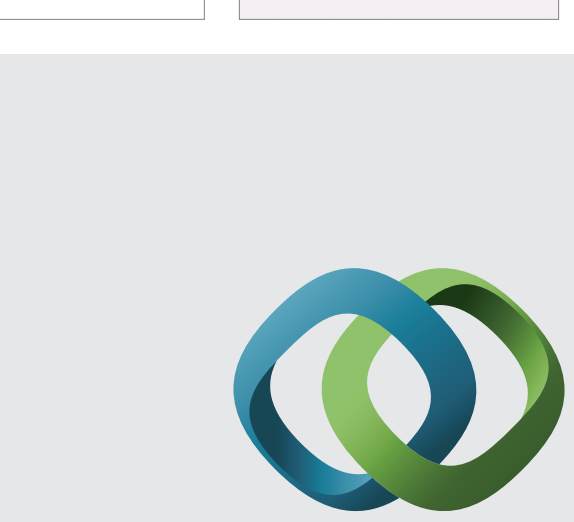

\section{Hindawi}

Submit your manuscripts at

http://www.hindawi.com
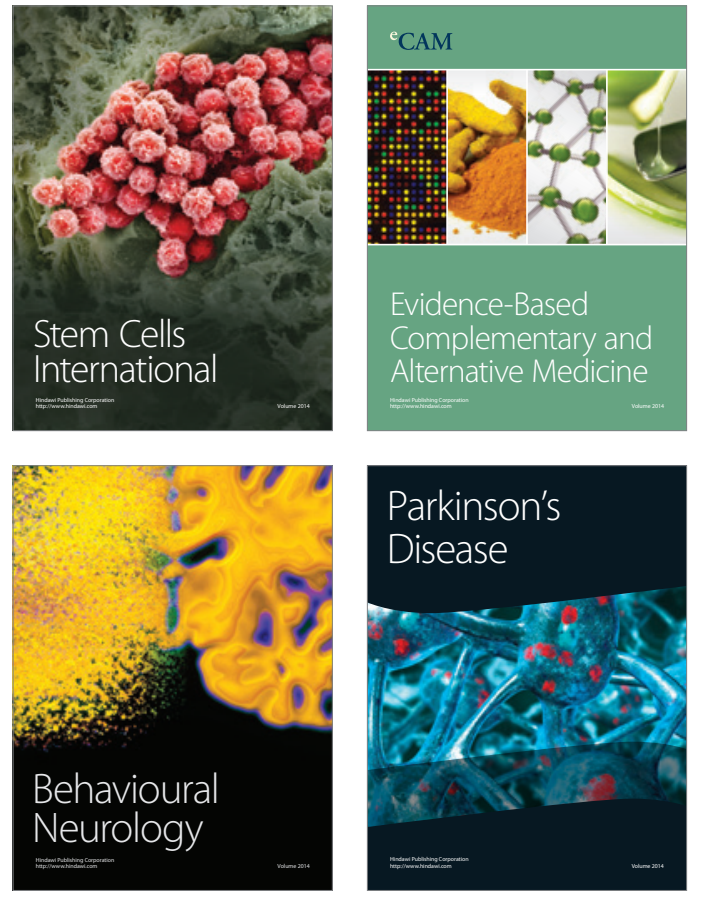
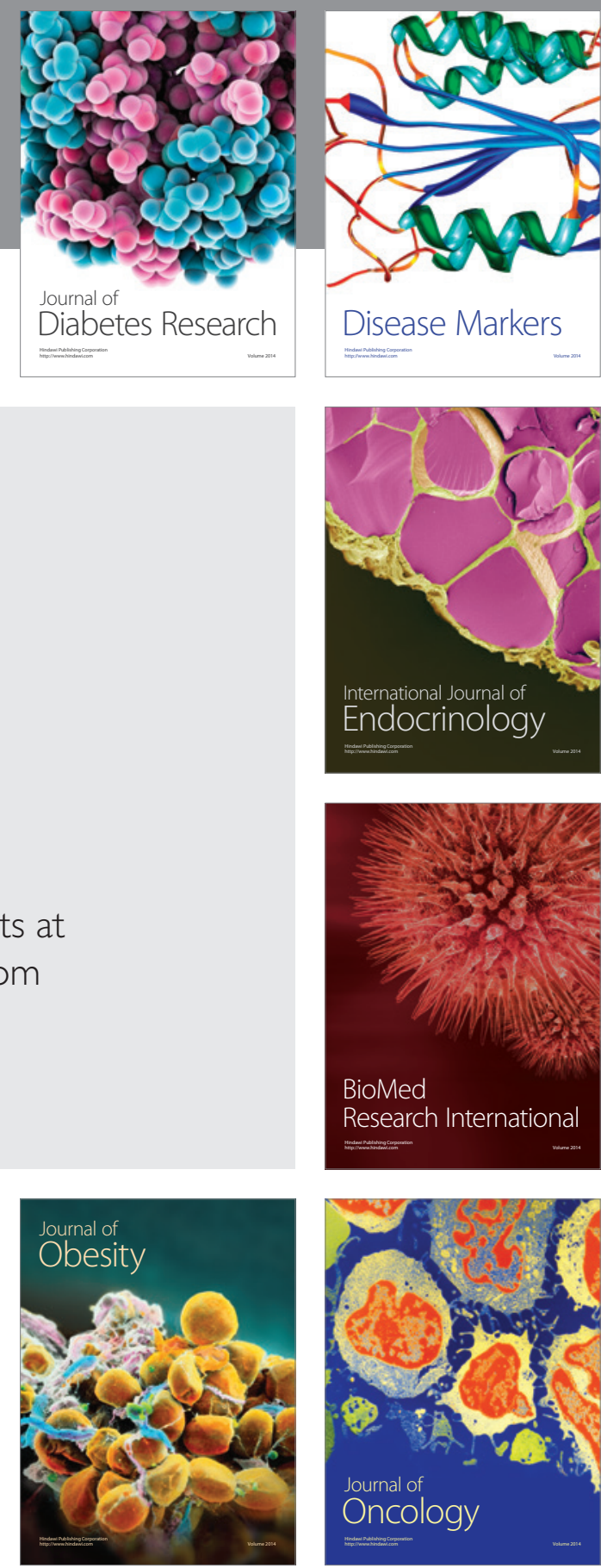

Disease Markers
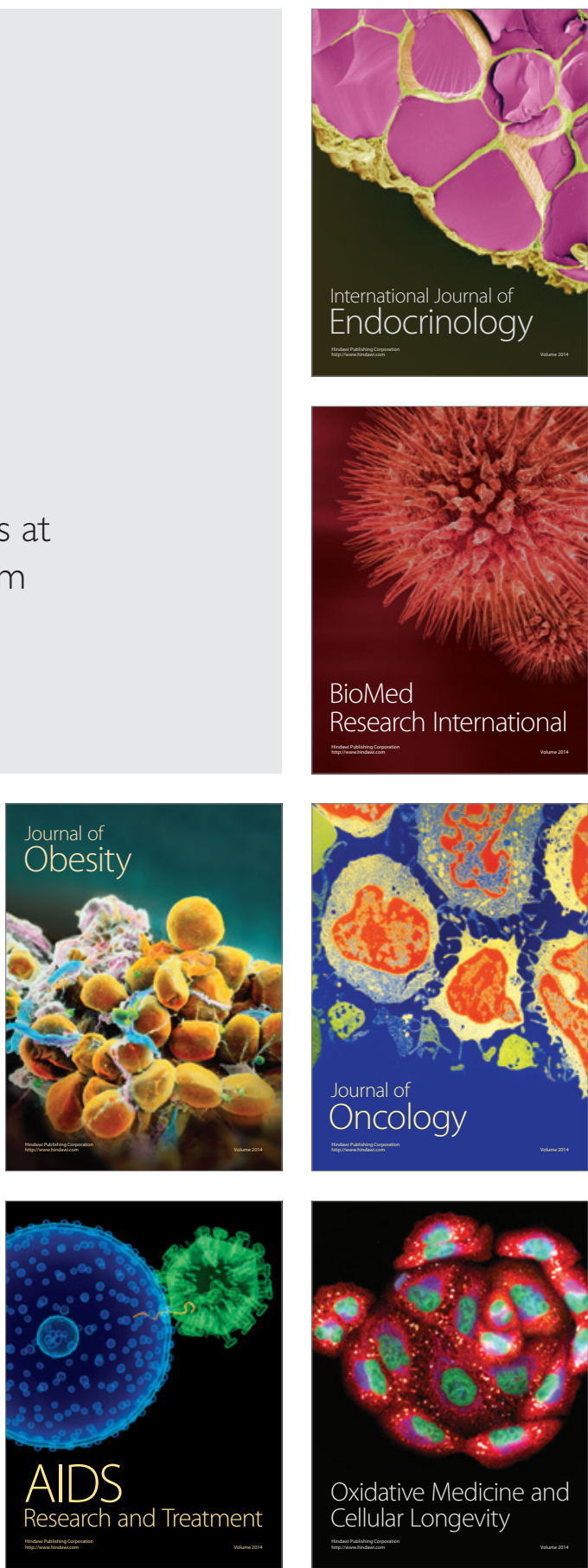